\title{
IS THE END OF TELEVISION COMING TO AN END?
}

\author{
Jérôme Bourdon \\ Department of Communication \\ Tel Aviv University \\ Haim Lebanon Street \\ Ramat Aviv, 69978 \\ Israel \\ jerombourdon@gmail.com
}

\begin{abstract}
This article analyses the discourses of the end of television in relation to its status as a bad object. It traces the early, transnational, massive negative treatments of television. It suggests four explanations for this: sociological (television as a popular medium), economical (disappointing investment), metapsychological (frustrating experience), technological (insincere dispositif). It suggests that discourses of the end are coming to an end, because television is becoming a kind of archive, increasingly considered nostalgically, while its 'quality series' are achieving canonical aesthetic status. Finally, it suggests that discourses of the ends are organized into systems of interdependent 'good' and 'bad' media.
\end{abstract}

Keywords: transnational history, intellectuals and television, economics, sociology, metapsychology, archive, nostalgia, media axiology.

'I hate television. I hate it as much as peanuts. But I can't stop eating peanuts' (Orson Welles, 1956).

Focusing on television, this article proposes a critical analysis of the 'discourse of the end' of a medium. ${ }^{1}$ I suggest that 'discourses of the end' (either the 'desirable end', or the 'dreaded end') affect certain media more than others, and in different tonalities, for reasons which have little to do with the actual possibility of identifying a precise 'end' to a given 'technology'. To be blunt: for the most part, writing about the end of a medium is about ideology, not history. It is ideologies that I am trying to track down. Television, as we will see, is a medium of choice for such an exercise.

In this analysis, discourses of the end cannot be detached from axiology: that is, the end of a medium is usually presented either as desirable or fearable according to a certain evaluation of the medium per se (often, regardless of actual content or genres proposed through such a medium). In the case of television, its end started being discussed as desirable quite early in its history, because of a massive evaluation of TV as a 'bad object', with contextual variations but a remarkable core of common arguments across countries.

I start with a short history of the major 'discourses of television'. After a short period of television utopia(s), television has been vilified and its end presented as highly desirable. This trend is not over but much weakened today. Second, I try to explain the potency of this discourse of the end: why has television been the target of such hatred? Third, I suggest that

1 This text elaborates on an inaugural conference given at 'Fiktsia. The 4th television studies conference', Department of Cinema and Television, Tel Aviv University. I would like to thank the organizers and the participants for many helpful suggestions in the discussion which followed. 
the discourse of the end seems to be... coming to an end, for (at least) three interrelated reasons: television is becoming, largely, a kind of archive (but the meaning of the term is changing, too, and television has something to do about it). Television can be considered nostalgically. And, finally, some television productions are reaching a new aesthetic status, as 'quality television' (in quotes: again, this is not about ontology: the desperate search for quality also has a history, which we cannot recount here). In conclusion, I will make proposals for comparisons between discourses of the end, and suggest that they are organized according to specific systems where 'good' and 'bad' media are deeply interdependent.

\section{Before the Bad Object: the Short Honeymoon with Television}

The discourse of the bad object did not start instantly. There was a more positive perspective on television in its early years. Television (just like radio before, but also cinema to a certain extent) inherited pedagogical ambitions for a tool which was supposed to reach a mass audience (adding to radio the seduction of the image). Television was considered as giving a 'major opportunity'2 to education, with some research supporting the thesis of the educational potential of the medium, including by well-known sociologists ${ }^{3}$. The UNESCO supported such efforts. An encouraging international evaluation of $1960^{4}$ is entitled 'Television teaching today': 'Television teaching': this phrase then referred to teaching with, or through, television; later, it would mostly be understood as the teaching of 'critical skills' for (young) television viewers, in order to thwart the (bad) influence of the medium. If you will: teaching television against television.

Briefly, television was also considered as giving birth to a new art form, somewhere between cinema and theatre. Some cinema scholars moved to television, and so did some cinema critics. Live drama, especially, was much discussed ${ }^{5}$, in relation to a specific aesthetics of television.

\section{Early Skepticism and Hostility}

However, at slightly different paces, both ambitions receded quickly. While, as numerous historians have noted, 'new' technologies in the modern age have triggered cycles of hopes and disappointments, (see conclusion), the wave of hope about television was short lived, and disappointment came early, from numerous quarters.

Skepticism or hostility from educational quarters came first, despite the efforts to set up networks of educational television. The long lament about the bad effects of television had already started in the 1960s, and earlier in the US (famously in the 'vast wasteland' speech of FCC chairman Newton Minnow). As for the art form, the remarkable hostility of cinema (as a milieu, and also as scholarship) did not wait long to express itself, for example in this comment by a famous French critic, André Labarthe, in 1961 in the cultural magazine La Nef: 'Television is not an art of the real, as cinema, but a technology of the real, as the telephone'. This tradition of cinema critics attacking television has barely relented since, especially in France. In the 1980s, Serge Daney, ${ }^{6}$ a renowned cinema critic turned television reviewer for a short period, published a selection of his reviews as a book, which read as a scathing

2 Jean Cazeneuve and Jean Oulif, La Grande Chance de la Télévision, Calmann-Lévy, 1963. For a history of early US utopias see the Predictions for Educational TV in the 1930s.

3 Example in France: Michel Crozier, 'Télévision et développement culturel', Communications 7, 1966, 11-26.

4 Henry R. Cassirer, Television Teaching Today, Paris, UNESCO, 1960. Late positive assessment: George N. Gordon, Classroom Television: New Frontiers of TV, Hasting House, 1970.

5 See e.g. for Western Europe: Jérôme Bourdon, Juan Carlos Ibanez, Catherine Johnson and Eggo Müller, 'Searching for an Identity for Television: Programmes, Genres, Formats', in Jonathan Bignell and Andreas Fickers, eds, European Television History, Blackwell, 1998.

6 Serge Daney, Le salaire du zappeur. Ramsay, 1988. A sample of Daney in English. 


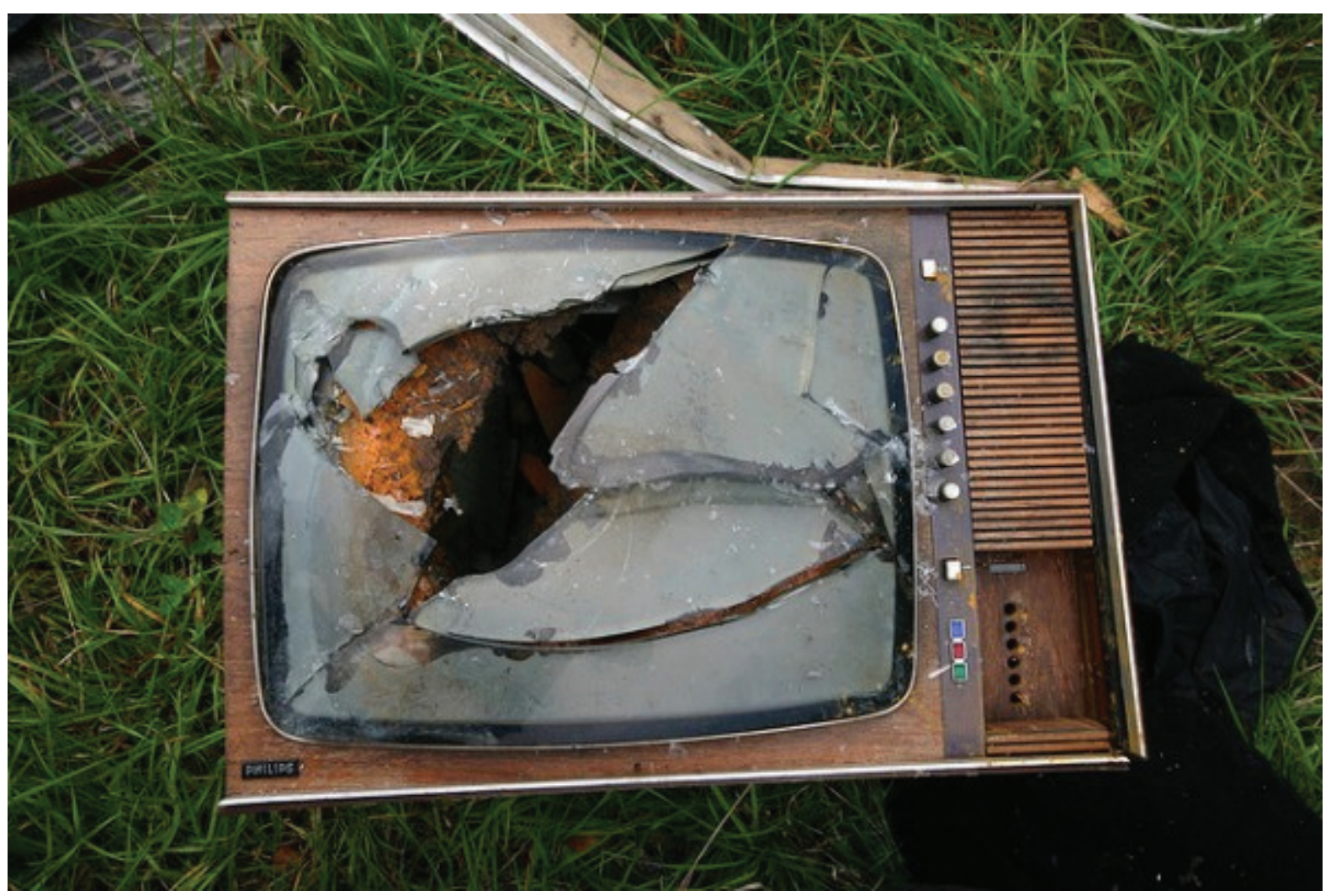

Figure 1. One of the innumerable destroyed TV sets available on Google Images.

attack on the medium, on all fronts: political, aesthetic, if not psychoanalytic, together with an indictment of a society which has begotten such a medium.

Western television critics, after attempts to construct it as a good object (mostly artistic, sometimes journalistic), switched their axiological orientations around the end of the sixties. Some intellectuals, such as Maurice Clavel in France, used television to comment about society. Some journalists turned television critics seemed to have taken a peculiar enjoyment in thrashing the medium, echoing cinema critics. Finally, television journalism became service journalism, informing on what was about to be broadcast and helping viewers make a choice. ${ }^{7}$

\section{The Triumph of Hatred}

The discourse of the desirable end of television cannot be separated from the long perception, at least among cultural and political elites, of television as a 'bad medium', or as 'bad object'. It is impossible to even mention all prestigious intellectuals, philosophers, and sociologists who took part in this vilification. Although I will generalize about cultural elites across Western nations, it is worth bearing in mind that precise cross-national comparisons remain to be made. It would be interesting to dig out similar attacks beyond the Western world.

As examples of national contexts: In the UK, the association of television with theatre and its specific British history, may have reduced the intensity of the aggressiveness against television. In Italy, much as in France, there were 
J. Bourdon, Is the End of Television Coming to an End?

additional political reasons for the resentment of left-wing intellectuals: until the 1970s, public television was under the domination of the main, right-wing party in power, the Italian Christian Democrats or the French Gaullist party.

In Italy, Pasolini, not only a film-maker but a leading public intellectual, was the most popular television prosecutor. On December 9, 1973, he published his challenge to television managers, in the popular daily Corriere della Sera, with much success. Pasolini came back to the topic of television numerous times. He early wrote about the televisionpolitics nexus (as if foreboding the rise of TV-Prime Minister Berlusconi). Still in Italy, more academic and less famous authors also took television to task ${ }^{8}$. Major publishing houses also translated books attacking television (Bourdieu, Postman, or the Enzensberger, all referred below).

There were a few successful international anti-television pamphlets. In 1977, Jerry Mander, former advertiser turned advocate of the public interest published his Four arguments for the elimination of television, translated into Italian, Spanish and German and probably other languages. ${ }^{9}$ In 2007, Jerry Mander could be still interviewed about television in an apocalyptic political documentary entitled: What a way to go, life at the end of the empire, where television joins climate change as one of the major ailments of humankind.

In France, philosophers, while not writing specifically about television, occasionally produced damning statements, often remarkable for their triviality (regardless of the rest of their work). Literary theorist Maurice Blanchot rephrased the cliché of the passivity of the viewer and claimed that television substituted to 'actual practice, the pseudoknowledge of an irresponsible gaze'. ${ }^{10}$ In a dark essay on modern times, famed phenomenologist Michel Henryclaimed that television was the 'acme' of barbarity. ${ }^{11}$

In late stages of their careers, two 'huge' academic names, one British, one French, Karl Popper and Pierre Bourdieu proposed full-fledged indictments, on the basis of oral interventions turned into books (which may tell us something about the need to communicate against television, before theorizing it), both translated into major European languages. ${ }^{12}$ Bourdieu's book was originally a program directed by Gilles Lhôte and produced by the prestigious College de France where he held the Chair of Sociology. The book adapted from the program was most successful. It sold 100.000 copies in France and was translated into 26 languages.

Among scholars, the American academic Neil Postmanprobably made the biggest splash besides Bourdieu: Amusing ourselves to death was translated into French, German and Italian the year of its publication, among other languages. ${ }^{13}$ Postman's text started as a presentation to the 1984 Frankfurt Book Fair: the publishing industry enjoyed, it seems, the schadenfreude of an attack against the bad, rival medium.

\section{The Core Arguments against Television}

Those attacks on television share common characteristics. First, and importantly for us, they take to task the medium in itself, not (or rarely) a specific genre, or a specific regulation (let us say, private versus public television). No other

8 A political scientist: Giovanni Sartori, Homo videns: televisione e post- pensiero, Laterza Bari, 1999; a philosopher: Antonio Pierreti, Manifesto contro la televisione. La Scuola Brescia, 2000.

9 Jerry Mander, Four Arguments for the Elimination of Television, Harper Collins, 1977; German translation: Schafft das Fernsehen ab! Eine Streitschrift gegen das Leben aus zweiter Hand. Rowohlt, 1979; Spanish translation: Cuatro buenas razones para eliminar la television, Gedisa, 1981 (reprint 2010); Italian translation (20 years after the original): Quattro argomenti per eliminare la televisione, Dedalo Barri, 1996.

10 Maurice Blanchot, L'entretien infini, Gallimard, 1969, p. 358.

11 Michel Henry, Barbarism, Continuum, 2012 (original French edition 1987).

12 Karl Popper, Television, a Danger for Democracy (translated into French and Italian), Pierre Bourdieu, Sur la télévision, Liber/Raisons d’Agir, 1996, now a major 'text' in television syllabi, much beyond France.

13 Neil Postman, Amusing Ourselves to Death, Public Discourse in the Age of Show Business, Twentieth Anniversary Edition, Penguin, 2005. 
medium was criticized at such a high level of generality. A good example is Hans Magnus Enzenberger's apocalyptic claim that 'all complaints about television are "irrelevant", as they can be all subsumed under a single one: the medium himself is putting the viewer into some sort of 'trance', regardless of specific contents'. ${ }^{14}$ Although one may hear in this statement an echo of the specific German fear of propaganda, the idea of television 'hypnotizing' its viewers is quite banal across countries and authors.

From this starting point, television is accused of causing deterioration in several fields: mainly politics, then education and culture. Politics was central to their argumentation: television is viewed as 'a danger for democracy' (Popper). The medium is supposed to concentrate huge power. With or without references to sociological work, television is also condemned for encouraging passivity among its viewers (but also, somewhat paradoxically, violence). Whether the harmful effects of television result from the technology itself (viewing a flow of images in the home), of the poverty of programs, of a deliberate political manipulation, is not always clear. In his book, Bourdieu seems to combine technological determinism and the idea that television is deliberately used as a tool of 'symbolic oppression'. Furthermore, writing at the time of the quick growth of commercial TV in France, he also criticizes, in passing, the purportedly paternalistic public service television of the past.

A personal note, here: for French academics of my generation, the USA and the UK were places where we thought that television and popular culture were taken more seriously than in France, where television was established as a serious object of study. However, in later encounters with scholars from different Western countries, including the USA and the UK, we could all share our sense of working on a medium considered as 'bad object'15 by most of our colleagues, if not our highly educated acquaintances.

\section{Persisting Marginal Support from the Television Ind u s try}

An exception should be made for a specific bunch of authors, coming mostly from the television industry, who have kept writing books in praise (or defense) of television, across the years. They often adopted, as a kind of provocation, a resoundingly positive title for their books. In France, against the massively dominant advice of educators, advertiser Mariet urged parents to 'let children watch television'. ${ }^{16}$ Advertisers or media entrepreneurs would come back to praising television at regular intervals, most recently in the digital age, as a business model able to attract advertisers' money through popular genres. ${ }^{17}$ But this has always remained an isolated trend (strong mostly in the US).

\section{Why So Much Hatred?}

How can we explain this remarkable negative libidinal investment in television? One could of course simply claim that the attackers are right, in several ways: TV programs do have little cultural value; their accumulation in the brain of people does provoke bad effects. Obviously, I beg to differ, but I will not debate programs, in general or specifically. I will first note that their sheer mass made, and makes, any judgment of specific cultural value rather complicated, but

14 Hans Magnus Enzensberger, 'Das Nullmedium oder Warum alle Klagen über das Fernsehen gegenstandslos sind', in Peter Glotz, ed., Baukasten zu einer Theorie der Medien. Kritische Diskurse zur Pressefreiheit. Reinhard Fischer, 1997, originally published in Der Spiegel, 1988. Italian translation, Per non morire di television, Lupetti, 1990.

15 See for the US, Michele Hilmes, 'The Bad Object: Television in the American Academy', Cinema Journal, 45,1, Fall 2005, whose conclusions can easily be extended to other countries.

16 François Mariet, Laissez les enfants regarder la télé, Calmann Lévy, 1989.

17 Michael Wolf, Television is the New Television: The Unexpected Triumph of Old Media in the Digital Age, Portfolio/Penguin, 2015. 
this has never stopped critics from issuing blanket judgments on television as 'bad', or on cinema as 'good' (so the actual appreciation of texts is not at stake). Neither will I quote the numerous pieces of research which have all expressed scepticism regarding any strong, widespread effects of television. Ironically, the only indisputable effect of mass communications, and television in particular, might have been the massive production of a discourse on effects.

I will link our critics to a tradition which can be called, broadly, deterministic. They come from various intellectual milieus, and yet, all converge when it comes to make absolute claims about the effects of television. Unless one shares their dark determinism, the explanation cannot be found in the medium itself, but, rather, in a conjunction of sociological and psychological factors. Such a powerful collective hatred, shared by an international educated class, is over-determined. I will propose four explanations which can be jointly used.

\section{The Sociological Explanation: Taste, Class and Television (Bourdieu, Differently)}

I will start with a classic sociological explanation, relying on Bourdieu's notion of distinction ${ }^{18}$. Television hatred appears as the best way for intellectual elites to rationalize their disgust for television as the ultimate popular/vulgar medium in stratified societies. Contempt is key to distinction here. Historians told us how the medium was soon (and quickly, considering the early high price of TV sets) adopted as popular entertainment ${ }^{19}$. Not having television, or watching little television (or, 'only cinema', or 'only news', that is, respectable political or cultural genres) quickly became a strategy of negative distinction, as opposed to the positive distinction which could be reached by the consumption of books and movies. In various countries, the rate of non-owners has long remained the highest among university professors.

From this sociological explanation, I move to three hypotheses which do not refer to a specific class of haters, but assume that 'loving television' may have be a problem for all its viewers, which is trickier to claim, as we would need surveys about the relative evaluation of media in the whole population (I will quote one below). In addition, such surveys should take into account the power of highbrow television haters to impose their own 'problématique'20 on 'ordinary' television viewers. In other words: the dominant ideas on television may have been the ideas of the dominant classes. My three remaining explanations could partly hide a rationalization of the contempt of elites for television, happy to discover that everybody has a reason for hating the medium.

\section{The Economic Explanation: Television as Disappointing Investment}

This explanation is based on Hirschman's famous discussion ${ }^{21}$ of the ways some goods offer more or less satisfaction to consumers. It applies well to television, although Hirschman does not mention it. Television as a material, durable good requires (especially in its early days) a strong financial investment, but does not provide corresponding gratifications. One of the main characteristics of television consumption is that it does not offer 'closure', a moment where consumption comes to an end, can be retrospectively appreciated, and other successful moments of consumption can be planned.

18 Pierre Bourdieu, Distinction: A Social Critique of the Judgment of Taste, Harvard University Press, 1987 (original French edition 1979).

19 Jérôme Bourdon, 'Old and new ghosts. Public service television and the popular, a history', European Journal of Cultural Studies, 7,3, 2004.

20 In Bourdieu's terms, again: Pierre Bourdieu, 'L'opinion publique n'existe pas,' Questions de sociologie, Minuit, 1984 (original publication of the article in 1973).

21 Albert Hirschman, Shifting Involvements, Private Interests and Public Action, Princeton University Press, 1981. 
However, dissatisfaction with television has an additional, paradoxical characteristic. In Hirschman's terms, in general, dissatisfaction can lead to 'exit' (abandoning the goods for others) or 'voice' (protesting and asking for 'better television'). But not in the case of television: as has been oft noted (including by Orson Welles, quoted as epigraph above), unhappy television viewers keep watching much television. It could be tempting to offer a class-based explanation: heavy viewers depend on television for their leisure and do not have the time, or the money, to go out, especially as television is perceived as 'free'. Without dismissing this explanation, one will note that viewers of different statuses and classes have debated the addictive power of television viewing, which requires more than a purely class-based explanation.

\section{The (Meta)psychological Explanation}

From an explanation about the characteristics of consumer goods, maybe combined with class, we move to a more general psychological explanation, contrasting, then again, television with cinema. In a seminal article, Beverley Houston ${ }^{22}$ writes in terms similar to Hirschman's, but with a very different theoretical and disciplinary basis: metapsychology. Importantly, Houston insists that she writes about US commercial television, and its constant flow of multiple channels based on the promotion of consumption. Yet, as we will see, her claim could be generalized to public (service) television, inasmuch as it has also tried to attract the viewer constantly, especially as soon as competition existed between channels (including as few as two or three).

Houston contrasts the remarkable completeness of the cinema experience with television. Ignoring the viewing on films on the small screen, Houston analyzes cinema viewing as a specific, collective, dream like experience, paid for each time, outside the home, in dedicated places. As television is constantly available in the home (and, at some point, became available the first days of a viewer's life), the television experience can be described as constant flow, as an endless search for a satisfaction which can never be reached. Television does not offer a specular position, a moment of fulfilment through identification with characters of a given story, but something very different: 'a (never-fulfilled) dream of wholeness and the lack that monitors it', or 'taking pleasure in something like the terror of desire itself' (p. 203). 'Of cinema, we say: I want the cinema experience again, of television we say: I always want I as I have never had it' (p. 207).

In a critical political economy of desire, Yuran ${ }^{23}$ emphasizes the central place of television which attaches a 'sublime, unreachable quality' to ordinary people (who became celebrities) and ordinary objects (which becomes brands). Like Houston, he insists on the dialectics of desire and frustration. This analysis can be connected with sociological surveys of the level of satisfaction linked to different activities. In 1995, 'when activities are rated in general, watching TV rates notably below other leisure activities such as active sports, socializing, interacting with children, or book/ magazine reading'24. People claimed to be more willing to give up on TV to do something else. But did they?

\section{0 (Pseudo)-liveness and Television False Sincerity}

Finally, a fourth explanation can be tied to a major characteristic of television, one which was sometimes constructed as its defining promise ${ }^{25}$ : liveness, in major genres like news, entertainment, and later reality television. From the start, however, liveness could be staged: apparent liveness provided by continuous editing, the direct address, references to

22 Beverley Houston, 'The metapsychology of endless television consumption', in Michael T. Caroll and Eddie Tafoya, eds, Phenomenological Approaches to Popular Culture. Bowling Green Popular University Press, 2000 (original paper published in 1984).

23 Noam Yuran, What Money Wants. An Economy of Desire, Stanford University Press, 2014.

24 Joan P. Robinson and Steven Martin, 'Of Time and Television', The ANNALS of the American Academy of Political and Social Science, 625, $2009,83$.

25 Tara McPherson, 'Reload:Liveness, Mobility and the Web', in Wendy H.K. Chun and Thomas Keenan, eds, New Media, Old Media: A History and Theory Reader, Routledge, 2006. 
current affairs occurring in the world 'here and now', could differ from actual liveness ${ }^{26}$. Dealing with another related problematic promise of television, Ellis ${ }^{27}$ has suggested that television, which has been busy filming other people's and their faces, posed, very early, the question of the sincerity of performance: 'television has changed values as it breeds suspiciousness: because of the incessant diet of deception and insincerity'. Not only people who appeared live could have been recorded, but, in non-fiction genres, they could act in a non-authentic manner, and quickly become 'actors of themselves', in journalist Jean Daniel's prescient words ${ }^{28}$.

This weakness of television liveness is reinforced by the specific problematization of the concept of liveness within theater and performance studies. While the term 'live' was originally used to contrast immediate transmission versus recording of broadcast (radio) content, liveness is now used in performance studies to emphasize the fact that audiences experience a spectacle in the same space and time as the performers. In one of the first major theoretical statements about this type of liveness, Peggy Phelan ${ }^{29}$ prioritized the authentic, ephemeral liveness of performance, as opposed to the false, vicarious television experience. Although Auslander ${ }^{30}$ refuted Phelan with an economic and social analysis of performance, he also expressed reservations about television, said to have 'colonized' liveness, a claim which sounds ironical to television scholars.

\section{Love at Last? Or Just Nostalgia?}

This long period of hate for television might be coming to an end, although vigorous pamphlets are still written against the medium. As a recent French example: a doctor Michel Desmurget has recently promoted a book entitled: 'TV Lobotomie', on a highly 'scientific' basis (neurosciences). ${ }^{31}$

How did the discourse of television change? ${ }^{32}$ First, another communication medium has taken centre stage as the new technological revolution: the Internet. When the Internet is compared to other media, it is, mainly, to the printing press. ${ }^{33}$ In this context, television as a single, specific medium, either good or bad, simply matters less in public and academic discourse. Although audiences, including internet audiences, still watch many programs which belong to the traditional genres of television (including the most recent, reality television), the idea of the flow of genres, organized in a schedule, on a few channels, and viewed on a dedicated television screen, is now considered as a past experience, at least for the young generations of the Western world. This has allowed some commenters to turn television into a good medium as it became (or was felt to become) a past medium, which could easily trigger nostalgia in a contemporary age obsessed with memory and increasingly defined by a longing for an idealized past.

Nostalgia, however, is a complicated feeling, including in relation to the experience of media. ${ }^{34}$ I propose a distinction between institutional nostalgia, as expressed by researchers or professionals, for television as it used to be organized,

26 Jérôme Bourdon, 'Live television is still alive. On live television as an unfulfilled promise', Media, Culture and Society 22,5 , 2000.

27 John Ellis, 'The performance on television of sincerely felt emotions', The ANNALS of the American Academy of Political and Social Science, $625,2009$.

28 Jean Daniel, 'Viviane ou l'immobile', Les Cahiers de la Télévision, 2, 1963.

29 Peggy Phelan, Unmarked: The Politics of Performance, Routledge, 1993.

30 Philip Auslander, Liveness. Performance in a Mediatized Culture, Routledge (2 ${ }^{\text {nd }}$ edition), 2008. For a review of the debate, Suk-Young Kim, Liveness, Performance of Ideology and Technology in the Changing Media Environment, Oxford Online Encyclopedia of Literature, 2017.

31 Michel Desmurget, TV Lobotomie. La vérité scientifique sur les effets de la television, J'ai Lu, $2013 / 2011$.

32 I cannot address all the aspects of this change here. I am concerned mainly with changes which go beyond the realm of the academy, and touch 'secular' audiences. Other changes are more strictly academic. For example, the partial reevaluation of television as a 'feminine' media, unjustly treated in relation to a more 'masculin' cinema. For an early discussion, still worth reading, see Patrice Petro, 'Mass Culture and the Feminine: The "Place" of Television in Film Studies", Cinema Journal, 25, 3, Spring 1986.

33 Jérôme Bourdon, 'The case for the technological comparison in communication history', Communication Theory 28, 2018, 89-109.

34 Katarina Niemeyer, ed, Media and Nostalgia, Palgrave MacMillan, 2014. 


\section{TV LOBOTOMIE}

LA COBEMA ORGANISE UNE CONFERENCE SUR LES DANGERS de La télévision aVec Michel DESMURGET.

\section{SAMEd. 21 jANVIER $2012 * 14$ H30 -17 H30 * MarSellLe 13015}

PAF : $5 \boldsymbol{\varepsilon} \cdot$ CONFIRMATION ET LIEU AU COURRIEL : TVLOBOTOMIE@LAPOSTE.NET

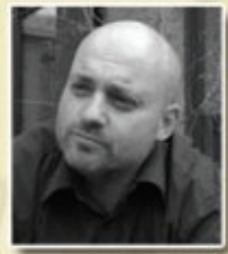

\section{MICHEL DESMURGET}

DOCTEUR EN NEUROSCIENCES

LE LIVRE SERA DISPONIBLE SUR PLACE ET DÉDICACE, SI SOUHAITE, PAR L'AUTEUR.

CTtaTION :

"LA RELATION ENTRE VOLLNCE DES MEDUS ET VOLENCE DE LA VIE REEUE EST EN FATT $A$ PEU PRËS AUSSI FORTE QUE LA RELATION ENTRE TABAGSSE ET CANCER DU POUMON".
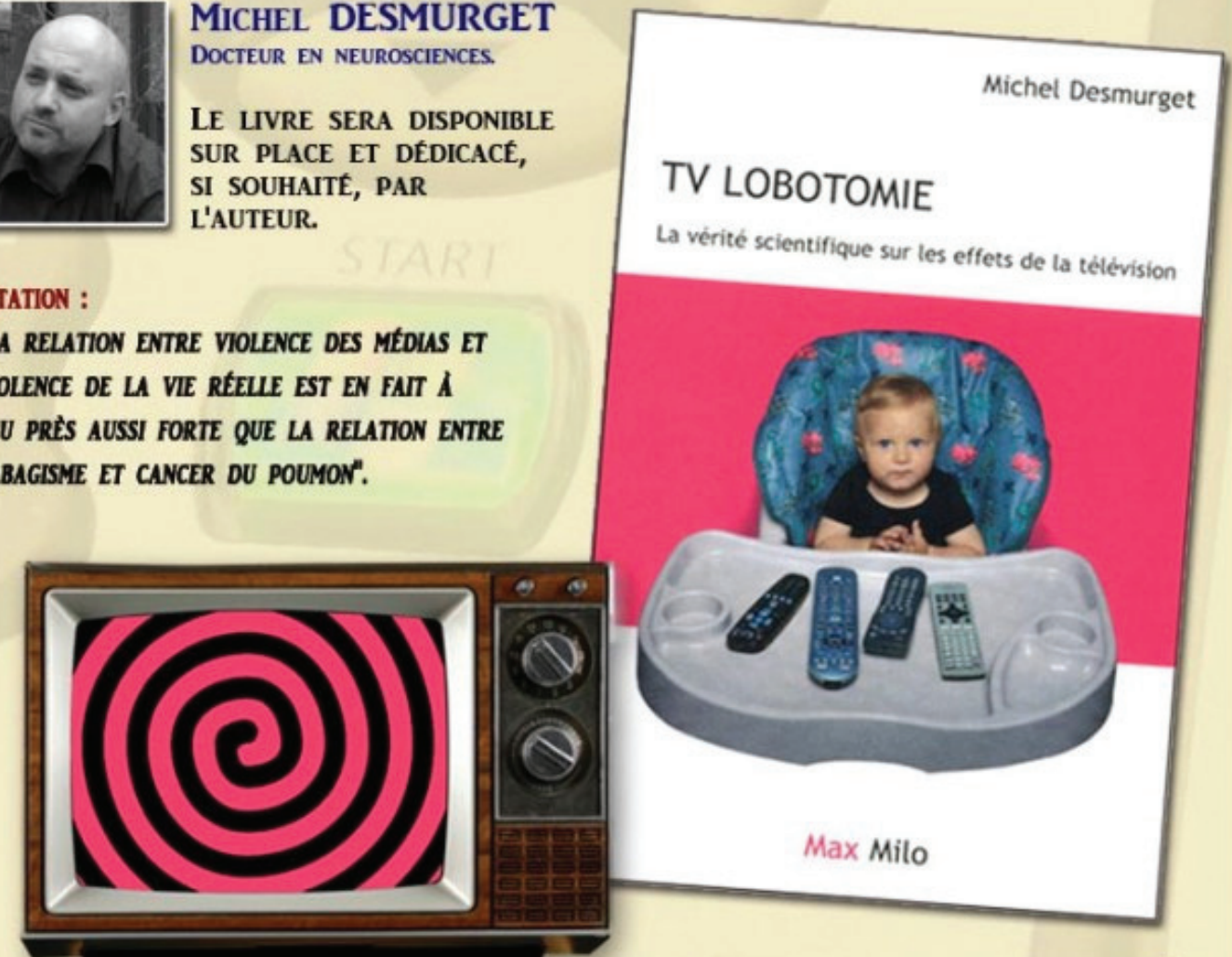

VU LE CONSTAT D'ABRUTISSEMENT GENERALISE dES MASSES, VU LA GRAVITE DE LA SITUATION QUI EN DECOULE, LA COBEMA ORGANISE CETTE CONFERENCE SUR LA PUISSANCE DE LA TÉLEVISION ET SES CONSÉQUENCES CONCRETES SUR LES TÉLESPECTATEURS aVEC M. DEsmURGet aUteUR dU LUVE SALVATEUR "TV LOBOTOMIE". 
as mass medium, and, especially, as a public mass medium, and social nostalgia, based on nostalgic experiences triggered by television viewing, sometimes actively sought, and also increasingly marketed by various channels including through the use of the name 'the nostalgia channel'. ${ }^{35}$

\section{Institutional Nostalgia: the Lost Forum}

The first way television could retrospectively be constructed as a good medium is tied to its capacity to draw mass audiences, once considered one of the major sources of its evil power. In the USA, and later in France, this aspect of television was redeemed and the drawback became an advantage: television was a 'cultural forum' which could draw vast populations to share, and debate, common social preoccupations. ${ }^{36}$ A most successful formulation was Elihu Katz's, ${ }^{37}$ who gave his article the parodic name of a prayer to be 'delivered from segmentation'. In the 1990s, the common mass consumption of the same programs (with high ratings, if not highly rated) was increasingly seen as a factor of social integration, not a political or social threat. ${ }^{38}$

In Western Europe, institutional nostalgia partly overlaps another theme, the lament about public service television (or broadcasting), which started at about the same time. ${ }^{39}$ In that case the regretted forum is tied to a certain kind of programming, focusing on 'high journalism', ${ }^{40}$ quality current affairs, drama, as opposed to entertainment and reality television (seen as a corruption of current affairs). Although it might be exaggerated to write that one has moved from 'fear of television' to 'fear for television', ${ }^{41}$ the question of the capacity of a medium to create an actual agora or forum (metaphors from the Antiquity are no coincidence here) is what matters.

Television researchers who focus on specific content would probably contest, then again, such sweeping statements. If we believe the example of Dutch television fiction, it might well be that (still) mass television has not always been busy with providing a common national narrative, but early used for questioning national identity and its components, for example promoting the regional as a new 'lieu de mémoire', ${ }^{42}$ as Sonja de Leeuw wrote. The notion of the forum or agora needs much refinement to be operationalized, and nostalgia is not a good emotional place to start such an investigation.

\section{Social Nostalgia: Television As (Past) Window on the Past World}

Besides nostalgia for institutional arrangements, television programmers, through the recycling/rearranging/ rescheduling of specific programs, can provide viewers with nostalgic experiences. Some programs focus on past experiences, and viewers experience mediated nostalgia (nostalgia for an actual past experience: remember this

35 Ekaterina Kalinina, 'The Flow of Nostalgia. Experiencing Television from the Past', International Journal of Communication, $10,2016$.

36 Horace Newcomb and Paul Hirsch, 'Television as a Cultural Forum, Implications for Research', Quarterly Review of Film Studies 8, 3 , 1983. Dominique Wolton praised 'la television de masse' in Éloge du Grand Public, Flammarion, 1990.

37 Elihu Katz, 'And Deliver Us from Segmentation', The Annals of the American Academy of Political and Social Science, vol. 546, 1996. See also Elihu Katz, ed, The Ends of Television, The ANNALS of the American Academy of Political and Social Science, 625, 2009.

38 Jean-Samuel Beuscart et al, 'La fin de la télévision? Recomposition de la television et synchronisation des audiences de la télévision de rattrapage', Réseaux, 43, 2012.

39 Michael Tracey, The Rise and Fall of Public Service Broadcasting, Oxford University Press, 1998.

40 Nicholas Garnham, 'A Response to Elisabeth Jacka's ‘Democracy as Defeat', Television and New Media, 4, $2,2003$.

41 Enli Gunn, Hallvard Moe, Vilde Schanke Sundet, and Trine Syvertsen, From Fear of Television to Fear for Television, Media History, $19,2,2013$.

42 Sonja de Leeuw, 'Television fiction. A domain of memory. Retelling the Past on Dutch Television', in Ann Gray and Erin Bell, eds, Televising

History, Mediating the Past in Postwar Europe, Palgrave MacMillan, 2010. 
foodstuff we were eating). But television can also rebroadcast or repackage past series, and then viewers can experience media nostalgia, properly speaking (remember this series we were watching together).

The different forms of nostalgia can overlap, as television programs can rely on various experience of the past, and project characters in the past world, and even play with this contrast within a given program, such as in the British series Life on Mars (2006-2007). ${ }^{43}$ Nostalgia can be a transnational phenomenon, as when Israeli viewers long for a past that belongs to a foreign country, when watching Mad Men (2007-2015). Media nostalgia can overlap the institutional nostalgia mentioned above, especially when viewers watch again a program which they saw when television was a collective family/national experience.

\section{Beyond Nostalgia: the Series, As the "New" Good Genre of Television}

The second major way to rehabilitate television has been tied to the rise of an old genre in a new context: the fiction series (limited to a few seasons, with high production values), viewed as 'quality series' which transformed television into a semi-cinematic medium, worthy of the same 'deep' textual criticism as cinema. ${ }^{44}$ The creator of such series, the showrunner, was also elevated to the rank of original creator, with more success that previous drama creators, such as the US TV producer and the French or Italian director. ${ }^{45}$ This re-evaluation of television is the object of an academic debate, between the relativists who see aesthetics as an instrument of power between media and genres, in a sort of zero-sum game about aesthetic value, and those who (rightly, in my view) ask that aesthetic judgment about television be recognized as a legitimate task, albeit a difficult one.

Regardless of this debate, context matters. Premium cable channels and digital platforms rely on subscriptions, not on the constant pressure of ratings which have to be delivered to advertisers, which leaves more room for manoeuver to content creators. With the growth of cable and satellite TV, more recently of digital companies like Amazon or Netflix, television has provided a number of series granted with the status of 'quality television'. ${ }^{46}$ This is an international phenomenon, yet to be researched in full.

HBO has been the first major channel associated to quality television. It started in 1975, and was soon imitated outside the US. It inspired the French Canal Plus (started 1984) which, some ten years ago, was at the origin of a critical turn in French television, deemed (at last) able to produce 'quality series', à l'américaine, which sometimes helped re-evaluation series of the 1960s and 1970s.

This partial rehabilitation, however, does not affect the image of the whole medium of television. As a symptom of this resilience of the television's badness, niche/quality channels have often marketed themselves as NON-television in order to ensure their reputation (imagine a film director proudly claiming he was NOT doing cinema). Witness the famous commercial, 'It's not TV, it's HBO'.

The claim that television is 'dying' may be another way to get rid of the bad object. Television has been 'buried' prematurely, quite a few times (for example, any decline is daily viewing time could be interpreted as a sign of an irreversible decline of the medium). In the 1990s, many scholars turned to the theme of 'the end of television', or 
'post-television'47. They noted (or claimed?) that television viewing of various genres was no longer structured around major broadcasting channels. Television was supposed to become just one more interface for watching content. Video in general, especially on the internet, could promise what television could not deliver, in short, good television at last... or not television at all, depending on the authors ${ }^{48}$.

\section{The Archive and the Rehabilitation of Television}

Finally, the 'archival turn' has also changed the status of the television text which becomes a trace of a precious history, worth preserving. ${ }^{49}$ One could envisage a scenario where television could be canonized, like cinema, with courses in the history of television proposing a justified chronology of creators and oeuvres. Even in the UK, where television was probably most valued, such efforts have fallen short of producing a cannon, as television value lies (lay?) much in producing a successful moment of social synchronicity, which goes together with a sense of the ephemerality of the medium ${ }^{50}$.

Television's 'archival turn' is actually about a constant reshuffling of the status of texts, the opposite of what the word 'archive' originally suggested: an orderly classification managed by public authorities certifying the status of text. The (supposedly) public service task of orderly classification is also deeply changing. Digitization and indexation multiply the possibility of treatment of the archives. Research must start with a 'better understanding of the tools' 51 available to the researcher. Experiencing only with keywords and tags, researchers can produce vastly different timelines for the same corpus.

Here, television becomes a minor good object for a minority, no longer a threatening massive bad object. In addition, as part of a new archival world, television, beyond orderly accessible libraries, also dissolves into a mass of semiburied, semi-accessible video texts of uncertain status, much like happens to texts in general in the digital world. This latches onto another problem: in a world where one can appropriate, sample, cut or process various texts freely, sometimes hiding their origins, the border between archive and creation is also threatened.

\section{Comparing Media, Comparing Their Ends}

Fantasized, desired and feared ends occupy a special place in the history of media discourses, which is (or should be) different from the discourses of researchers ${ }^{52}$ although, as we saw, there is much overlapping. It takes a special kind of idealization or demonization for the end of specific media to be fantasized, either positively or negatively. Some

47 Peter D’Agostino and David Tafler, eds, Transmission: Toward a Post-Television Culture, Sage, 1994; Jean-Louis Missika, La fin de la television, Seuil, 1999; Marc Leverette, Brian L. Ott, and Cara Louise Buckley, It's not TV: Watching HBO in the post-television era, Routledge, 2008; Michael Strangelove, Post-TV. For a conceptualization of 'quality' television drama as post-television: Itay Harlap, Television Drama in Israel. Identity in Post-TV Culture, Bloomsbury, 2016.

48 Mitchell Stephens, The Rise of the Image, the Fall of the Word., Oxford University Press, 1998; Michael Strangelove, Post-TV. Piracy, Cordcutting and the Future of Television, University of Toronto Press, 2015.

49 Sonja De Leeuw, 'European Television History online, archive and connectivity', VIEW, The Journal of European Television History and Culture 1,1, 2012, which analyzes the challenges of this digital archival turn for the television researcher.

50 John Ellis, 'Importance, significance, cost and value. Is an ITV canon possible?' in Catherine Johnson and Rob Turnock, eds, ITV Cultures: Independent Television Over Fifty Years, Open University Press, 2005.

51 Jasmijn Van Gorp, Sonja de Leeuw, Justin van Wees and Bouke Huurnink, 'Digital Media Archeology. Digging into the Digital Tool Avresearcherxl', VIEW, The Journal of European Television History and Culture, 4,7, 2015.

52 Andreas Fickers, 'Neither good nor bad nor neutral. The historical dispositif of communication technologies', in Michael Schreiber and Clemens Zimmerman, eds, Journalism and Technological Change. Contemporary Trends, Historical Perspectives, Campus Verlag, 2014. 


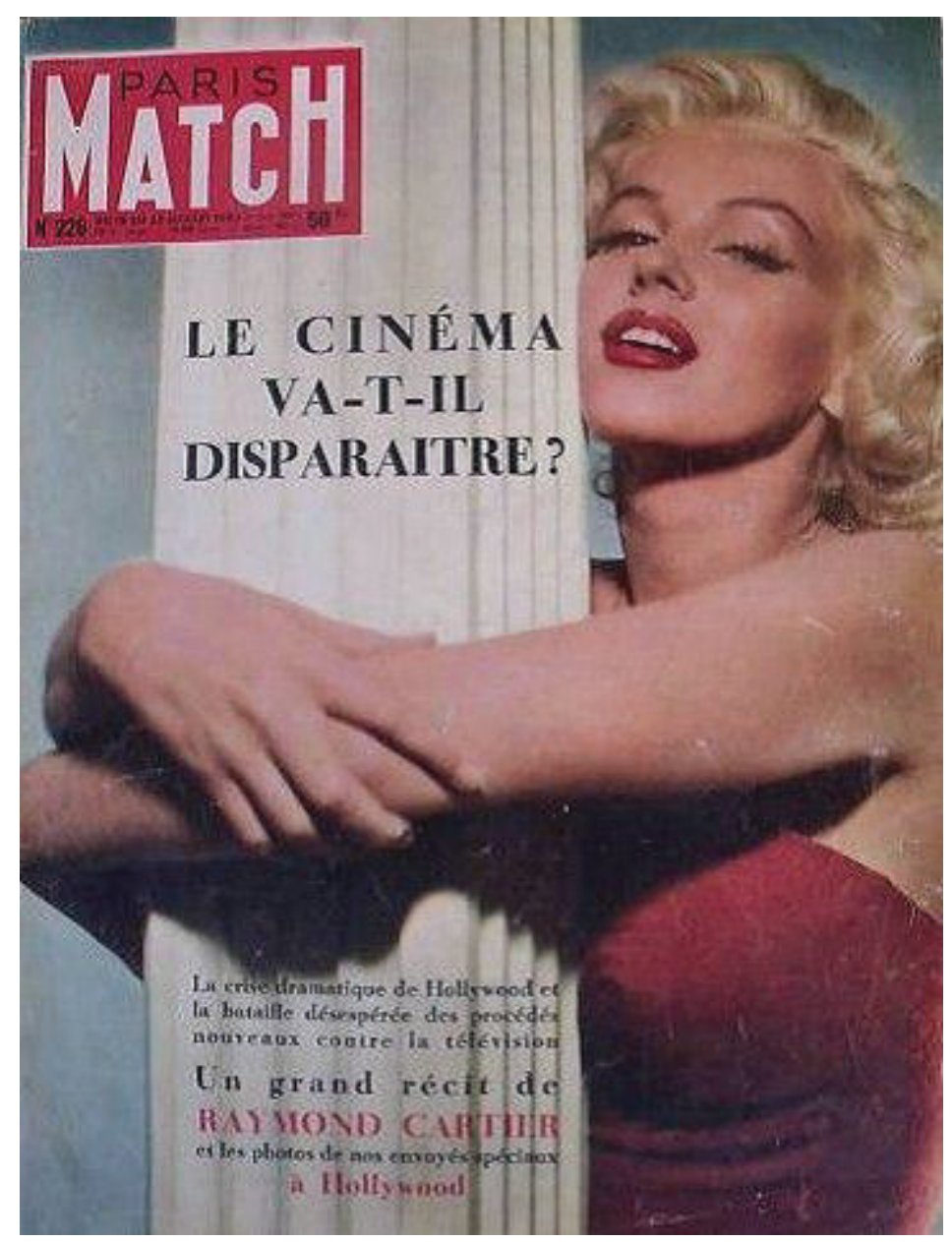

Figure 3. Cover of the popular French magazine Paris-Match, 1953: "Will cinema disappear?" The culprit: television.

media never had an end worth discussing, others have been discussed as 'about to end' for years (and proved, in most cases, remarkably resilient).

For example, at least after the rise of television, radio was neglected, or absorbed into a discourse about broadcasting with, mostly, television examples. Telegraph triggered a considerable enthusiastic discourse in the $19^{\text {th }}$ century, then was incorporated in social life as a professional tool of communication while other, more 'massive' media drew public attention.

By contrast with neglected media, three media especially can be said to have triggered a discourse of feared death, with a variety of laments and elegies. The 'Golden Palm' of the loved medium (but some would contest the use of the word medium here) goes to cinema. Although cinema, before television, was once considered as a perverse influence on the youth ${ }^{53}$, it was also, from the 1950 s onwards, contrasted with television as the good object threatened by the bad one ${ }^{54}$. Cinema has early been considered as both art and popular culture, what television failed to be (the 'art of the gutter', l'art du ruisseau, wrote French poet Pierre Reverdy in 1933). In 1953, a famous French journalist back from Hollywood worryingly asked 'will cinema disappear?' on the front page Paris-Match (226, July), the French equivalent of the American Life. While on the cover of the magazine, the glamorous star, Marilyn, embodies cinema,

53 See Herbert Blumer, Movies and Conduct, MacMillan, 1933.

54 A classic example is Noel Burch, 'Narrative/Diegesis-Thresholds, Limits', Screen, 23,2, July-August 1982. 
the culprit of this threatened disappearance appears in small letters at the bottom of the page: the nascent television, against which cinema is launching a 'desperate battle'.

Since then, laments on the end of cinema have been many. ${ }^{55}$ The threat today is supposed to come less from TV than from digital media and their relentless commercial flow promoting impermanence at the expense of the movie archivist, a servant of quality, art, history and public service: such dichotomies abound in The Death of Cinema, History, Cultural Memory and the Digital Dark Age, written by a melancholic archivist. ${ }^{56}$ Note the way the good medium is humanized: it does end, but dies, and we have to mourn it. Of course, the relation of cinema to 'new media' is more complicated. As new media have generated their own positive utopia, some scholars have been tempted to 'help' cinema through an association with new media, thus bypassing television in the history of audiovisual representations. This strategy was prophesized by Hilmes in 2005 , and is still in use. ${ }^{57}$

Another typical good medium is print, generally identified with a single output, the book. But the history of the discourses of print cannot be easily simplified. The original relation to print was ambivalent, both 'divine art' and 'infernal machine', ${ }^{58}$ both a way to bring education to mankind, or, e.g. for conservative forces like the Catholic Church, a way to spread evil influences. Eisenstein, however, notes how print quickly benefited from a positive image, reflected in... print itself. Especially, once print was enrolled as a major ally by enlightenment philosophers, and later by mass educators in the $19^{\text {th }}$ and $20^{\text {th }}$ century, the book became the ultimate 'good cultural object', in a quite physical sense, and is still treated so, for example by historian-archivist Robert Darnton..$^{59}$ Like cinema, the book has been personalized and triggered melancholic elegies, ${ }^{60}$ included a recent imaginary, epic biography of a fragile, persecuted character, called 'the book'. ${ }^{61}$

\section{Media Systems of Axiology}

Media systems of axiology, of contrasted good and bad objects, need to be considered. Print (the book), and cinema, have both been constructed as good objects by opposition to television. Print and the Internet have now been compared, for a few years, as two major positive 'revolutions' in the history of mankind.

Here, the popular psychoanalytic metaphor of the 'bad object' deserves to be taken seriously. As Buffy the Vampire Slayer taught us, 'television is the bad screen and the Internet is the good screen' (here comes a new contrast). Such systems of axiology can change quickly. ${ }^{62}$ And, as Melanie Klein taught us, the good and the bad objects intrinsically depend on each other. Indeed, it might be the same real-life object, the maternal breast, which plays the part of bad

55 Alongside laments, praises for cinema never stopped, sometimes with unexpected angles. Renowned French critic Jean-Michel Frodon celebrates the inherently 'democratic nature', which allows 'real people' to be embodied on screen, no matter the level of dramatization, in La Projection nationale. Cinéma et Nation, Odile Jacob, 1998.

56 Paolo Cherchi Usai, The Death of Cinema, History, Cultural Memory and the Digital Dark Age, BFI, 2001.

57 In 2017-18, the department of cinema and television at Tel Aviv proposes a course entitled: 'Empathy and assimilation in cinema and new media'.

58 Elisabeth Eisenstein, Divine Art, Infernal Machine, The Reception of Printing in the West from First Impressions to the Sense of an Ending, University of Pennsylvania Press, 2005.

59 Robert Darnton, The Case for Books: Past, Present and Future, Perseus, 2009. Note, however, that the paperback was once considered as a threat making texts accessible to numerous ignorant masses: Ben Mercer, 'The Paperback Revolution. Mass circulation books and the cultural origins of May 68 in Western Europe', Journal of the History of Ideas, 72, 4.

60 Sven Birkerts, The Gutenberg Elegies: The Fate of Reading in an Electronic Age, Faber, 1995.

61 Camille de Toledo, Le Livre de la Faim et de la Soif, Paris, Gallimard, 2016.

62 The Internetphilia once criticized by James Curran and Jean Seaton (Power Without Responsibility. Press, Broadcasting and the Internet in Britain, Routledge, 2009, $7^{\text {th }}$ edition) is no longer central to public (and academic) discourse. Most successful attack on the Net so far (repeating much of what was said on TV): Nicholas G. Carr, The Shallows: What the Internet Is Doing to Our Brains, W.W. Norton, 2010. See also his discussion on the book. 
and good object, so reversals can be expected (as seems to be happening for the Internet). Elaborating on the psychoanalytic metaphor, the use of the 'good/bad objects' opposition at the level of whole societies could much enrich our analysis of our relation to media as crucial technologies in the construction of our social identities. ${ }^{63}$

\section{Biography}

Jérôme Bourdon is a professor at the Department of Communication at Tel Aviv University. Recent books: Television Audiences Across the World. Deconstructing the Ratings Machine (edited with Cécile Méadel), Palgrave, 2014. Du service public à la télé-réalité, une histoire culturelle des télévisions européennes, INA, 2011 (Italian translation:Vita e Pensiero, 2015). Recent articles: 'The case for the technological comparison in communication history', and 'Telepresence in history, from correspondence to computers', both in Communication Theory, 2018. More at: http:// telaviv.academia.edu/JeromeBourdon. 